\title{
Zinc-binding proteins from boar seminal plasma - isolation, biochemical characteristics and influence on spermatozoa stored at $4^{\circ} \mathrm{C}^{\star}$
}

\author{
Marzena Mogielnicka-Brzozowska1凶${ }^{\circledR}$, Paweł Wysocki, Jerzy Strzeżek and Władysław Kordan \\ University of Warmia and Mazury in Olsztyn, Department of Animal Biochemistry and Biotechnology, Olsztyn, Poland
}

\begin{abstract}
Affinity chromatography on Chelating Sepharose Fast Flow Gel-Zn ${ }^{2+}$ was used for fractionation of boar seminal plasma proteins. Approximately $30 \%$ of total boar seminal plasma proteins showed affinity for zinc ions ( $Z n B P$ fraction). Native electrophoresis (PAGE) of ZnBP revealed six protein fractions which separated into 27 bands under denaturing conditions (SDS/PAGE). Two-dimensional electrophoresis (2D PAGE) showed 148 polypeptides with isoelectric points mostly in the basic and neutral $\mathrm{pH}$ range. The zinc-binding proteins comprise mainly 10-20 kDa polypeptides which are probably members of the spermadhesin family. ZnBP present in the incubation mixture of spermatozoa stored for 1 or $24 \mathrm{~h}$ at $4^{\circ} \mathrm{C}$ allowed preservation of a higher percentage of cells exhibiting linear motility in comparison to a control sample stored in PBS. Presented results indicate that proteins binding $\mathrm{Zn}^{2+}$ ions have a shielding effect on the sperm plasma membrane and acrosome of spermatozoa, protecting these structures against consequences of cold shock.
\end{abstract}

Keywords: boar, spermatozoa, zinc, $\mathrm{Zn}^{2+-}$ binding proteins, cold shock

Received: 25 August, 2010; revised: 04 February, 2011; accepted: 06 May, 2011; available on-line: 17 May, 2011

\section{INTRODUCTION}

Numerous functions carried out by seminal plasma proteins result from their ability to bind low-molecular weight ligands, such as $\mathrm{Zn}^{2+}$ ions. They protect chromatin of spermatozoa and regulate their motility. Additionally, these protein ligands exert immunomodulating, antibacterial and antioxidant functions in the reproductive tract (Strzezek et al., 1987; Al-Somai et al., 1994; Vivacqua et al., 2004; Caballero et al., 2006, Edstrom et al., 2008).

Zinc stabilizes sperm chromatin in boar (Bjorndahl et al., 1990) and human (Vivacqua et al., 2004; Bjorndahl \& Kvist, 2010). In boar and human semen, $\mathrm{Zn}^{2+}$ ions and $\mathrm{Zn}^{2+}$-binding proteins, synthesized in a seminal vesicle gland, are the main modulators of chromatin stability (Strzezek 1999; Bjorndahl et al., 1991).

Proteins that originate in seminal vesicles are the major components of human semen coagulum, collectively named semenogelins (Sg) (Robert \& Gagnon, 1999). Semenogelins and their fragments have a high binding capacity for zinc ions secreted by the prostate gland and they shuttle $\mathrm{Zn}^{2+}$ to the sperm nucleus where they regu- late DNA stability (Robert \& Gagnon, 1999; de Lamirande et al., 2007).

Besides regulating sperm chromatin condensation, semenogelins exert other effects on spermatozoa, such as inhibition of movement (Robert \& Gagnon, 1999; de Lamirande et al., 2007; Yoshida et al., 2008), antibacterial activity (Edstrom et al., 2008), hyperpolarization of plasma membranes (Yoshida et al., 2008), and prevention of capacitation (de Lamirande et al., 2001).

Prostasomes — high molecular weight exosome-like vesicles, which occur in large quantities in the semen have been characterized as zinc binding structures in human (Ronquist \& Brody, 1985; Vivacqua et al., 2004). Prostasome-like vesicles have also been identified in stallion, boar, ram (Arienti et al, 1998; Gatti et al., 2005; Piehl et al, 2006) and rabbit semen (Mourvaki et al., 2010). They are surrounded by a lipoprotein membrane showing different catalytic proteins and an unusual lipid composition (Kravets et al., 2000). They are involved in different biological functions, such as enhancement of sperm motility (Carlsson et al, 1997), immunosuppression (Kelly, 1991), antioxidant action (Saez et al., 1998), and antibacterial activity (Carlsson et al., 2000).

During the epididymal sperm transit zinc elimination is a mandatory step in sperm maturation to obtain motility. Research of Henkel et al. (1999; 2003) showed that zinc is located also in the flagella, where it plays an important function in sperm motility regulation in humans. During spermatogenesis, when outer dense fibers (ODF) are formed, zinc ions bind cysteinyl residues in ODF and act as an antioxidant factor.

Zinc is present in human, bull, boar, rat and hamster spermatozoa and its removal by chelating agents causes

\footnotetext{
e-mail: mmog@uwm.edu.pl

ॠPreliminary report was presented at the 4th Symposium of the Society for Biology of Reproduction and Joint Polish-Japanese Seminar, 22-24 September, Kraków, Book of Abstracts, p 165.

Abbreviations: 2D PAGE, two dimensional polyacrylamide gel electrophoresis; CFDA, carboxyfluorescein diacetate; CUB, 100-110-residue spanning domains first reported in the complement subcomponents $\mathrm{C} 1 \mathrm{rC1s}$, epidermal-growth-factor-related sea urchin protein and bone morphogenetic protein 1; HBP, heparin-binding proteins, ODF, outer dense fiber; PAGE, native polyacrylamide gel electrophoresis; $\mathrm{PCH}$, phosphorylcholine; $\mathrm{PI}$, propidium iodide; PSA, prostate-specific antigen; PSP, porcine seminal plasma protein; SDS/PAGE, sodium dodecyl sulfate polyacrylamide gel electrophoresis; Sg, semenogelins; ZnBP, zinc-binding proteins from boar seminal plasma
} 
an increase in sperm motility (Silverstroni et al., 1989; Andrews et al., 1994).

A zinc-binding protein secreted by boar seminal vesicle glands has been isolated from the seminal plasma (Strzeżek et al., 1987; Strzeżek \& Hopfer, 1987). It possesses antibacterial properties and regulates sperm motility. However the molecular structure and polypeptide composition of zinc-binding proteins and their influence on the functions of spermatozoa subjected to different storage conditions have not been elucidated as yet.

In this study we isolated and characterized biochemically a zinc-binding protein fraction from boar seminal plasma and determined the effect of the isolated fraction on some quality parameters of sperm after its storage under cold shock conditions $\left(4^{\circ} \mathrm{C}\right)$.

\section{MATERIALS AND METHODS}

Preparation of seminal plasma. Boars used in this study were fed a commercial feed and kept in individual pens under standard environmental conditions. Approval of a local ethics committee was obtained for this study (No. 23/2003). Whole ejaculates were collected from ten sexually mature Polish Large White boars using the gloved-hand technique. The gel fraction was removed from the ejaculate using sterile gauze. Filtered semen samples were centrifuged for $15 \mathrm{~min}$ at room temperature at $10000 \times g$. The supernatant (seminal plasma) was stored at $-20^{\circ} \mathrm{C}$ until required. Before chromatographic separations seminal plasma was dialyzed for $24 \mathrm{~h}$ against deionized $\mathrm{H}_{2} \mathrm{O}$ and centrifuged $(15 \mathrm{~min}, 10000 \times g)$. Obtained supernatant was used for isolation of zinc-binding proteins $(\mathrm{ZnBP})$.

Protein measurement. The protein content was measured according to Lowry et al. (1951) using bovine serum albumin (BSA; Serum and Vaccine Production, Cracow, Poland) as a standard.

Separation of $\mathbf{Z n}^{2+}$-binding proteins. Separation of $\mathrm{Zn}^{2+}$-binding proteins was conducted on a BioPilot chromatography system with $500 \mathrm{ml}$ of Chelating Sepharose Fast Flow gel packed in an XK50 column (Amersham Biosciences). The column was equilibrated in 0.5 $\mathrm{M}$ Tris/ $\mathrm{HCl}, 0.5 \mathrm{M} \mathrm{NaCl}$ buffer $(\mathrm{pH} \mathrm{8.0)}$ ) and saturated with an aqueous solution of $\mathrm{ZnCl}_{2}$ (Sigma) until a concentration of $30 \mu \mathrm{M}$ of $\mathrm{Zn}^{2+}$ ions/ml of gel was obtained (Hoóody \& Strzezek, 1999). After the column had been washed with equilibration buffer, $100 \mathrm{ml}$ of dialyzed seminal plasma (20-50 mg proteins/ml) was loaded. $\mathrm{Zn}^{2+}$-binding proteins were eluted from the column with $0.5 \mathrm{M}$ Tris/ $\mathrm{HCl}$ buffer $(\mathrm{pH} 7.5)$ with $0.1 \mathrm{M}$ imidazole and collected as $10-\mathrm{ml}$ fractions. The column was regenerated with $0.5 \mathrm{M}$ Tris/acetate, $0.5 \mathrm{M} \mathrm{NaCl}$ and 0.5 $\mathrm{M}$ EDTA ( $\mathrm{pH}$ 7.0). The $\mathrm{ZnBP}$ fractions were dialyzed against deionized $\mathrm{H}_{2} \mathrm{O}$ and lyophilized.

Determination of molecular mass of $\mathrm{Zn}^{2+}$-binding proteins using gel filtration. A Superose 12 column and an FPLC (Fast Protein Liquid Chromatography) system (Amersham Biosciences) were used for molecular mass determination of isolated proteins under nondenaturing conditions. For calibration, the following molecular mass standards were used: ribonuclease (15.6 $\mathrm{kDa})$, chymotrypsinogen $(22.8 \mathrm{kDa})$, ovalbumin (48.9 $\mathrm{kDa})$, albumin $(65.4 \mathrm{kDa})$, aldolase $(146 \mathrm{kDa})$ and catalase $(226 \mathrm{kDa})$. Calibration and separation of protein fractions were conducted at a flow rate of $0.5 \mathrm{ml} / \mathrm{min}$ using $0.5 \mathrm{M}$ Tris/ $\mathrm{HCl}, 0.3 \mathrm{M} \mathrm{NaCl}$ and $0.02 \%$ (w/v) sodium azide ( $\mathrm{pH} 7.5$ ) buffer. The molecular mass of proteins was determined according to Andrews (1964).

Electrophoretic characterization of isolated proteins. Non-denaturing electrophoresis - PAGE (Davis 1964). Glass tubes $(0.5 \mathrm{~cm} \times 8.7 \mathrm{~cm})$ were filled with a $7.5 \%$ resolving gel solution to obtain $7.5 \mathrm{~cm}$ long gel. After polymerization a $0.5 \mathrm{~cm}$ layer of $4 \%$ stacking gel was added on the surface of the resolving gel. Tubes with polymerized gel were fitted in an electrophoresis chamber filled with electrophoresis buffer $(0.5 \mathrm{M}$ Tris, $0.25 \mathrm{M}$ glycine, $\mathrm{pH}$ 8.3). Samples $(200 \mu \mathrm{l}, 8 \mathrm{mg}$ of total protein $)$ were loaded on the gels and electrophoretic separation was performed at a constant current of $5 \mathrm{~mA} / \mathrm{gel}$. Gels were stained with $0.5 \%(\mathrm{w} / \mathrm{v})$ amido black in $7 \%(\mathrm{v} / \mathrm{v})$ acetic acid and destained with several changes of $7 \%$ acetic acid.

Denaturing electrophoresis - SDS/PAGE (Laemmli, 1970). Protein samples were diluted at a 1:1 ratio with 2 $x$ concentrated lysis buffer $(0.34 \mathrm{M}$ Tris $/ \mathrm{HCl}, 10 \% \mathrm{SDS}$ $(\mathrm{w} / \mathrm{v}), 20 \%$ glycerol $(\mathrm{v} / \mathrm{v}), 2 \% \beta$-mercaptoethanol (v/v), $2 \%$ bromophenol blue (w/v), $\mathrm{pH}$ 6.8) and heated for 5 min at $95^{\circ} \mathrm{C}$. Before loading, samples were centrifuged at $10000 \times \mathrm{g}$ for $5 \mathrm{~min}$ at room temp. Electrophoresis was performed in $12 \%$ polyacrylamide gels, $6.5 \mathrm{~cm}$ long, at a constant voltage $(120 \mathrm{~V})$ in a buffer containing 0.5 $\mathrm{M}$ Tris, $0.25 \mathrm{M}$ glycine and $0.5 \% \mathrm{SDS}(\mathrm{w} / \mathrm{v}), \mathrm{pH} 8.3$. Different amounts of protein were loaded in gel wells to obtain optimal resolution of protein bands occurring at various concentrations in the isolated $\mathrm{ZnBP}$ fraction. After electrophoresis, the gel was silver-stained according to Heukeshoven and Dernick (1985). Low molecular mass standards (Amersham Biosciences) and the MultiAnalyst software (BioRad) were used for polypeptide molecular mass determinations.

Two-dimensional electrophoresis - 2D PAGE (O'Farrell et al., 1977). 2D electrophoresis was performed using a Mini Protean II 2-D Cell (BioRad) and a $\mathrm{pH}$ gradient of 3.0-10.0. Before separation, proteins were purified using a Plus One 2D Clean-up Kit (Amersham Biosciences) according to the manufacturer's protocol. Obtained protein pellets were dissolved in $100 \mu \mathrm{l}$ of a solution containing $9.5 \mathrm{M}$ urea, 2\% Triton X-100 (v/v), 0.065 $\mathrm{M}$ dithiothreitol and 2\% ampholytes (v/v) ( $\mathrm{pH} 3-10)$. Gels for isoelectric focusing were polymerized in 0.1 $\mathrm{cm} \times 5.5 \mathrm{~cm}$ glass tubes from a solution containing 9.2 M urea, 4\% acrylamide (w/v), 20\% Triton X-100 (v/v) and $2 \%$ ampholytes $(\mathrm{v} / \mathrm{v})(\mathrm{pH} 3-10)$, and then preelectrophoresed $(200 \mathrm{~V}-10 \mathrm{~min}, 300 \mathrm{~V}-15 \mathrm{~min}$, $400 \mathrm{~V}-15 \mathrm{~min})$. Samples $(50 \mu \mathrm{l})$ were placed on the surface of the gel and overlayed with $20 \mu \mathrm{l}$ of a buffer containing 9.0 M urea, 1\% ampholytes (v/v) ( $\mathrm{pH} 3-10)$, $0.05 \%$ bromophenol blue $(\mathrm{w} / \mathrm{v})$. Isoelectrofocusing was performed at $500 \mathrm{~V}$ for $10 \mathrm{~min}$ and $850 \mathrm{~V}$ for $4.5 \mathrm{~h}$ using $0.1 \mathrm{M} \mathrm{NaOH}$ as the cathode buffer and $0.010 \mathrm{M}$ $\mathrm{H}_{3} \mathrm{PO}_{4}$ as the anode buffer.

After isoelectric focusing, gels were incubated in a buffer containing $0.625 \mathrm{M}$ Tris $/ \mathrm{HCl}, 2.3 \% \mathrm{SDS}(\mathrm{w} / \mathrm{v})$, $5.0 \%$ 2-mercaptoethanol (v/v) (Serva), 10\% glycerol $(\mathrm{v} / \mathrm{v})$ and $0.05 \%$ bromophenol blue (w/v), $\mathrm{pH} 6.8$ for $10 \mathrm{~min}$. After incubations the gels were transferred to the surface of $15 \%(6.5 \mathrm{~cm}$ long $)$ slab SDS/PAGE gels, covered with $1 \%(\mathrm{w} / \mathrm{v})$ agarose and electrophoresed in a buffer containing $0.5 \mathrm{M}$ Tris/ $\mathrm{HCl}, 0.25 \mathrm{M}$ glycine, $0.5 \%$ SDS (w/v), $\mathrm{pH} 8.3$ at $150 \mathrm{~V}$ until bromophenol blue reached the bottom of the gel.

Electrophoresis and staining of the gels were performed using procedures described for SDS/PAGE. Gel 
analysis was conducted using PDQUEST (BioRad) software.

The effect of $\mathrm{ZnBP}$ proteins on boar spermatozoa stored at $4^{\circ} \mathrm{C}$. Sample preparation. Characteristics of plasma membrane integrity, sperm morphology and linear movement were determined in the following incubation variants:

- Control (without ZnBP) — spermatozoa washed with PBS and suspended in PBS at a final concentration $3 \times 10^{7}$ cells $/ \mathrm{ml}$.

- Treatment (with $\mathrm{ZnBP}$ ) - spermatozoa rinsed with PBS and suspended in PBS supplemented with $3 \mathrm{mg} / \mathrm{ml}$ of the $\mathrm{ZnBP}$ fraction at a final concentration of $3 \times 10^{7}$ cells $/ \mathrm{ml}$.

Measurements were made after semen dilution (time 0 ) and after 1 and $24 \mathrm{~h}$ of incubation at $4{ }^{\circ} \mathrm{C}(277.2 \mathrm{~K})$.

Sperm motility (CASA). Motility of spermatozoa was measured using a CASA (Computer Assisted Semen Analysis) system (CMA-Mika System, Strömberg-Mika, Germany). Total motility of spermatozoa was assessed visually by the same technician throughout the study. For the assessments, aliquots $(6 \mu \mathrm{l})$ of diluted semen samples were placed on a pre-warmed slide, covered with a glass cover slide and examined under a light microscope (200× magnification) equipped with an attached heated stage $\left(37^{\circ} \mathrm{C}\right)$. Ejaculates used in the experiment showed an initial motility above $80 \%$.

The percentage of total motile sperm cells was calculated. Among the motile cells percentage of spermatozoa showing linear movement was determined using a CASA system.

Sperm morphology. Spermatozoa were Giemsa stained according to Watson's (1975) method. After smears were prepared on slides they were analyzed under a light microscope (Olympus CO 11) at a $100 \times$ magnification using an immersion lens. The percentage of cells with damaged acrosome was recorded.

Sperm plasma membrane status — fluorescence measurements. Sperm plasma membrane integrity was assessed using a combination of two fluorochromes: carboxyfluorescein diacetate (CFDA) and propidium iodide (PI) (both from Sigma, St. Louis, MO, USA), as described in a previous study (Fraser et al., 2002). Spermatozoa were examined under an epifluorescence microscope (Olympus CH 30, Tokyo, Japan). Spermatozoa showing PI staining were assumed to have damaged sperm plasma membrane. Two slides were assessed per sample and 200 spermatozoa were evaluated per slide.

Statistical analysis. Data were subjected to analysis of variance (ANOVA) using the General Linear Model (GLM) procedure from Statistica software package, version 8 (StatSoft Incorporation, Tulsa, OK, USA). All results are expressed as mean \pm standard error of the mean (S.E.M.), and were considered significant at $P<0.05$.

\section{RESULTS}

After separations on Chelating Sepharose Fast Flow gel, two protein fractions were obtained from boar seminal plasma. The first one contained zinc non-binding proteins eluted from the resin with equilibration buffer. The second fraction comprised zinc-binding proteins $(\mathrm{ZnBP})$ eluted with imidazole buffer. Planimetric analysis of chromatogram showed that the ZnBP constituted approx. 30\% of the total amount of seminal plasma proteins.

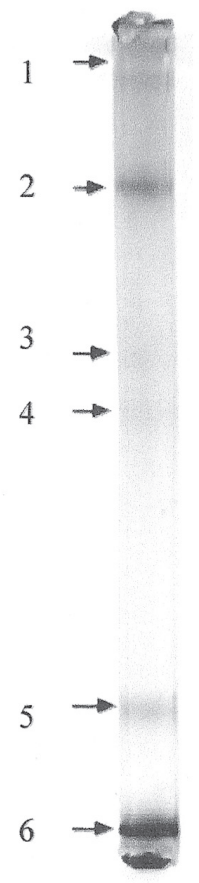

Figure 1. Native polyacrylamide gel electrophoresis (PAGE) of isolated zinc-binding proteins ( $\mathrm{ZnBP}$ ) from boar seminal plasma.

Electrophoresis of the $\mathrm{ZnBP}$ fraction under non-denaturing conditions (PAGE) showed the presence of six protein bands (Fig. 1). The molecular messes of two of them were determined at over $226 \mathrm{kDa}$ and the others were approx. 150, 85, 40 and below $15 \mathrm{kDa}$ (Fig. 2). The action of reducing and denaturing factors (SDS/PAGE) on native forms of $\mathrm{ZnBP}$ resulted in an increased heterogeneity of the analyzed sample. Electrophoregrams showed the presence of $27 \mathrm{ZnBP}$ bands from below 14 $\mathrm{kDa}$ to over $94 \mathrm{kDa}$ with those between 14 and $20 \mathrm{kDa}$ predominating (Fig. 3).

The polypeptide map (2D PAGE) (Fig. 4) showed that the $\mathrm{ZnBP}$ of boar seminal plasma consisted of 148 polypeptides, of which most had the isoelectric point (pI) within the $\mathrm{pH} 6$ to 10 range. Only few of them were acidic ( $\mathrm{PI}=3$ to 6 ). The molecular msses of the analyzed polypeptides ranged from below 14 to above $94 \mathrm{kDa}$.

Significant differences $(P<0.05)$ were found between the percentage of spermatozoa with linear motility after $1 \mathrm{~h}$ incubation in $4^{\circ} \mathrm{C}$ between the control without $\mathrm{ZnBP}$ and treated samples with $\mathrm{ZnBP}$. The proportion of spermatozoa with damaged acrosome were markedly lower $(P<0.05)$ in the treated samples (Table 1$)$.

Even though there were no motile spermatozoa in the treated samples the proportions of spermatozoa with damaged acrosome were lower $(P \leq 0.05)$ after $24 \mathrm{~h}$ incubation in $4^{\circ} \mathrm{C}$ in treated samples with $\mathrm{ZnBP}$ (Table 1).

After 1 and $24 \mathrm{~h}$ incubation in $4^{\circ} \mathrm{C}$ the percentage of spermatozoa with intact membranes (CFDA/PI stained) was higher $(P<0.05)$ in treated samples compared with control (Table 2).

\section{DISCUSSION}

We isolated zinc-binding proteins from boar seminal plasma $(\mathrm{ZnBP})$. Our results indicate that $\mathrm{ZnBP}$ in the native state form high-molecular mass aggregates (150 


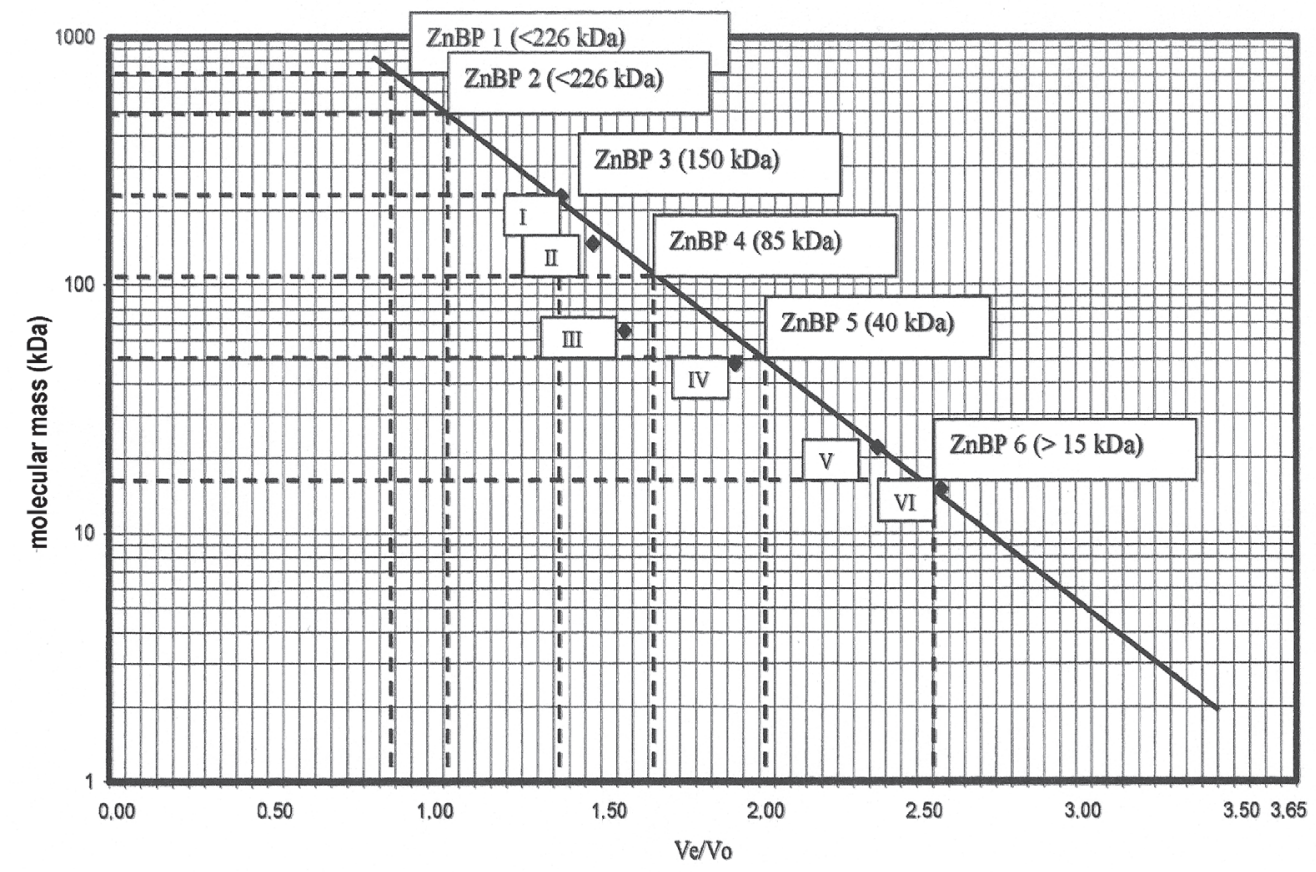

Figure 2. Gel filtration of isolated zinc-binding proteins (ZnBP) from boar seminal plasma

Molecular mass standards: I. catalase (226 kDa), Il. aldolase (146 kDa), III. albumin (65.4 kDa), IV. ovalbumin (48.9 kDa), V. chymotrypsinogen (22.8 kDa), VI. ribonuclease (15.6 kDa).

$\mathrm{kDa}$ and over $226 \mathrm{kDa}$ ) which dissociate under the influence of denaturing and reducing conditions.

These findings are in agreement with other authors' research, which showed that the processes of association and dissociation of native forms of seminal plasma proteins occur under the influence of different factors, including the presence of specific ligands and changes in the $\mathrm{pH}$ of the solution (Jelinkova et al., 2004; Jonakova \& Ticha, 2004).

Siciliano et al. (2008) found in boar seminal plasma high molecular mass prostasome-like vesicles which stimulated acrosome reaction. These structures under denaturating conditions showed molecular masses of 60 and $90 \mathrm{kDa}$.

Human seminal plasma contains main coagulum-forming proteins named semenogelins (Sg). Under denaturating conditions their molecular mass are $52 \mathrm{kDa}(\mathrm{SgI})$ and 71 or $76 \mathrm{kDa}(\mathrm{SgII})$. These are predominant zinc-

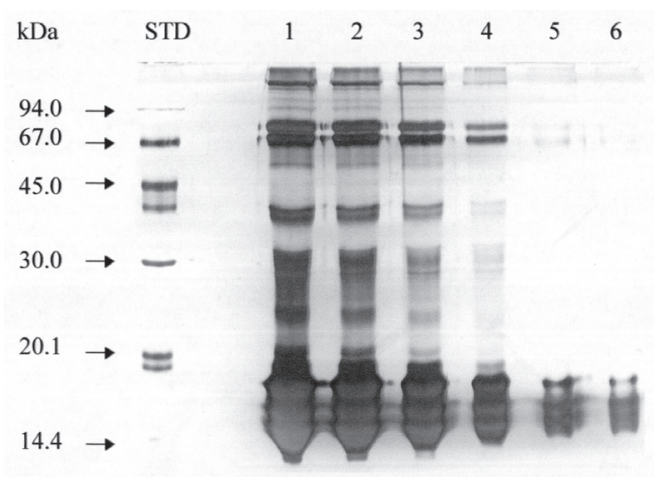

Figure 3. SDS/PAGE electrophoresis of zinc-binding proteins isolated from boar seminal plasma (ZnBP)

In lanes 1-6 decreasing amounts of proteins were loaded: 1) 70 $\mu \mathrm{g}$; 2) $58 \mu \mathrm{g}$; 3) $53 \mu \mathrm{g}$; 4) $40 \mu \mathrm{g}$; 5) $26 \mu \mathrm{g}$; 6) $13 \mu \mathrm{g}$. STD, low molecular mass standards (Amersham Biosciences). binding proteins in the human seminal plasma (Robert \& Gagnon, 1999).

Proteins of bull seminal plasma in their native state have a wide range of molecular mass from 5 to $500 \mathrm{kDa}$ (Shannon et al., 1987; Hameed et al., 1991). These are mainly high-molecular aggregates, which under the influence of low $\mathrm{pH}$ and in the presence of citrate are dissociated to low-molecular mass components (Al-Somai et al., 1994). In the human seminal plasma protein complexes with mass over $660 \mathrm{kDa}$ and approx. $250 \mathrm{kDa}$ were identified (Vivacqua et al., 2004).

We used two-dimensional electrophoresis (2D PAGE) to generate a peptide map of $\mathrm{ZnBP}$ isolated from boar seminal plasma. This method allows detailed identification of seminal plasma proteins participating in the fertilization process. This system has been used before to characterize seminal plasma proteins from different

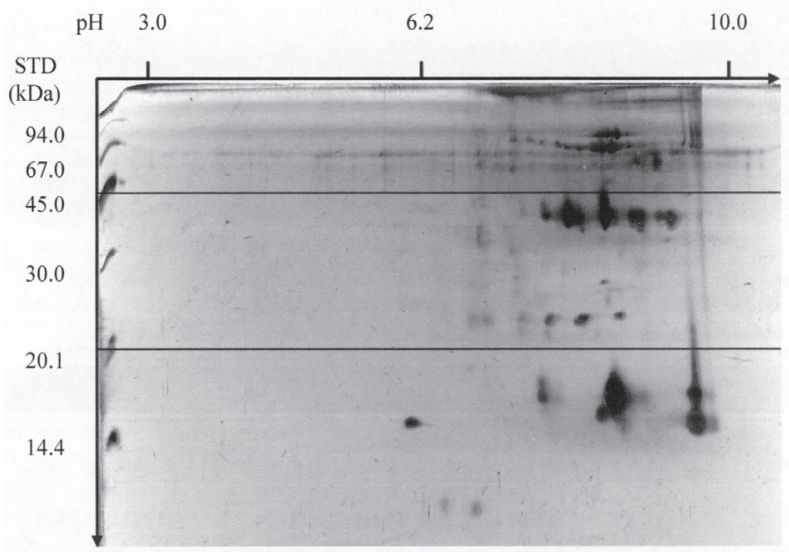

Figure 4. Two dimensional electrophoresis (2D PAGE) of zincbinding proteins isolated ( $\mathrm{nnBP}$ ) from boar seminal plasma STD, low molecular mass standards (Amersham Biosciences). 
Table 1. Percentage of spermatozoa exhibiting linear movement and spermatozoa with damaged acrosome

Time 0, after semen dilution and after incubation at $4^{\circ} \mathrm{C}$ for 1 and $24 \mathrm{~h}$. Control, spermatozoa incubated with PBS; Treatment - spermatozoa incubated with zinc-binding proteins $(\mathrm{ZnBP})$ from boar seminal plasma. $\mathrm{n}=10$. Values denoted with letters a, $\mathrm{b}$ differ statistically significantly at $P \leq 0.05$.

Incubation (h)

\begin{tabular}{|c|c|c|c|c|c|c|}
\hline \multirow[b]{2}{*}{$\begin{array}{l}\text { Incubation } \\
\text { variants }\end{array}$} & \multicolumn{2}{|c|}{$\mathrm{Oh}$} & \multicolumn{2}{|c|}{$1 \mathrm{~h}$} & \multicolumn{2}{|r|}{$24 \mathrm{~h}$} \\
\hline & $\begin{array}{l}\text { Linear motile } \\
\text { spermatozoa } \\
\%\end{array}$ & $\begin{array}{c}\text { Spermatozoa with } \\
\text { damaged acrosome } \\
\%\end{array}$ & $\begin{array}{c}\text { Linear motile } \\
\text { spermatozoa } \\
\%\end{array}$ & $\begin{array}{c}\text { Spermatozoa with } \\
\text { damaged acrosome } \\
\%\end{array}$ & $\begin{array}{c}\text { Linear motile } \\
\text { spermatozoa } \\
\%\end{array}$ & $\begin{array}{c}\text { Spermatozoa with } \\
\text { damaged acrosome } \\
\%\end{array}$ \\
\hline Control & $5.8 \pm 3.8^{a}$ & $10.8 \pm 6.9$ & $3.8 \pm 1.0^{\mathrm{a}}$ & $52.2 \pm 8.7^{a}$ & 0 & $80.0 \pm 5.7^{a}$ \\
\hline Treatment & $10.4 \pm 7.2^{b}$ & $6.9 \pm 4.7$ & $7.2 \pm 1.6^{b}$ & $35.5 \pm 4.1^{b}$ & 0 & $48.5 \pm 4.5^{b}$ \\
\hline
\end{tabular}

mammalian species, involved in the regulation of fertility and suitability of semen for cryopreservation (Brandon et al., 1999; Flowers et al., 2001; Killian et al., 1993; Jobim et al., 2004).

In this study all polypeptides of analyzed fractions under denaturing conditions (SDS/PAGE; 2D PAGE) mass from below $14 \mathrm{kDa}$ to over $94 \mathrm{kDa}$. The highest percentage of polypeptides was found within the range of molecular weights from 10 to $20 \mathrm{kDa}$ and a basic pI, which corresponded with molecular mass of zinc-binding peptides identified in human seminal fluid (Rehault et al., 2002; Fung et al., 2004). Analysis by 2D revealed their molecular mass $<30 \mathrm{kDa}$ and basic pI. These peptides were identified as truncated forms of semenogelins I and II. In physiological state they occur after prostate-specific antigen (PSA) action. This process is regulated by zinc ions (Malm et al., 2000; Jonsson et al., 2005). It is interesting that these peptides displayed antibacterial activity, while the holoproteins did not (Edstrom et al., 2008). Additionally, a direct MALDI-TOF-MS analysis of unfractionated human seminal fluid revealed the presence of $0.8-7.3-\mathrm{kDa}$ peptides, the majority of which were found to be derived from SgI (Fung et al., 2004). The same method was used to detect seminal basic protein, also a fragment of $\mathrm{Sg}$ I, that is belived to inhibit sperm motility (Robert \& Gagnon, 1999). A 19-kDa protein, probably derived from $\mathrm{Sg}$ processing, is present at the periphery of detergent-treated and sonication-resistant human sperm nuclei (Zalensky et al., 1993).

The low molecular mass polypeptides found on the $2 \mathrm{D}$ gels suggest the presence of spermadhesins in the analyzed fraction. Spermadhesins are synthesized by accessory sex glands of the male reproductive system and are deposited on the sperm surface during ejaculation (Sanz et al., 1992). According to Calvete et al. (1997) spermadhesins account for approx. $90 \%$ of the total protein in seminal plasma. In turn, two main spermadhesins in boar, i.e. PSP-I and PSP-II, represent over $50 \%$ of the total protein content of the seminal plasma (Rutherfurd et al., 1992).

Table 2. Percentage of spermatozoa with intact plasmalemma (CFDA/PI staining).

Time 0 , after semen dilution and after incubation at $4^{\circ} \mathrm{C}$ for 1 and $24 \mathrm{~h}$. Control, spermatozoa stored after dilution in PBS; Treatment, spermatozoa stored with zinc-binding proteins (ZnBP) isolated from boar seminal plasma. $n=10$. Values denoted with letters $a, b$ differ statistically significantly at $P \leq 0.05$.

\begin{tabular}{|c|c|c|c|}
\hline \multicolumn{4}{|c|}{$\begin{array}{l}\text { Membrane-intact spermatozoa (\%) } \\
\text { incubation }(\mathrm{h})\end{array}$} \\
\hline Incubation variants & $\mathrm{Oh}$ & $1 \mathrm{~h}$ & $24 \mathrm{~h}$ \\
\hline Control & $83.8 \pm 4.6$ & $16.1 \pm 1.7^{a}$ & $15.6 \pm 2.4^{a}$ \\
\hline Treatment & $84.6 \pm 3.7$ & $26.6 \pm 2.4^{b}$ & $21.5 \pm 3.8^{b}$ \\
\hline
\end{tabular}

The structure of spermadhesins is based on a combination of several modules, of which each contains a CUB fragment. It is a conserved domain containing in its structure four cysteine residues, between which two disulfide bridges are formed (Bork \& Beckman, 1993). It is a commonly known fact that bonds are formed between zinc ions and cysteine residues (Bjorndahl et al., 1990). Presumably this type of interaction may be the way of binding of zinc ions with spermadhesins containing CUB fragments.

Apart from the above-mentioned binding mechanism of zinc ions with proteins, $\mathrm{Zn}^{2+}$ affinity for phospholipids and lipoproteins also should be taken into account. Interactions of $\mathrm{Zn}^{2+}$ ions with phosphate groups and double bonds of unsaturated fatty acids are also possible (Bettger \& O'Dell, 1981). Moreover, zinc ions and proteins binding them may also bind heparin. This type of interaction is well known for the spermadhesin family (Björnadhl 1986; Hołody \& Strzeżek, 1999).

In boar spermatozoa, coating of the sperm membranes by plasma proteins may stabilize its structure (de Leeuw et al., 1990). Seminal plasma from good freezer boars has a positive effect on cryopreserved sperm function, among other things by enhancing their resistance to cold shock (Hernandez et al., 2007).

Heparin-binding proteins (HBP) and the PSP-I/PSPII heterodimer have an antagonistic effect on the viability, motility and mitochondrial activity of diluted spermatozoa incubated at $38^{\circ} \mathrm{C}$ for $5 \mathrm{~h}$. The HBP have a negative effect while PSP-I/PSP-II a positive one (Centurion et al., 2003).

It has been found that an addition of PSP-I/PSP-II to highly diluted $\left(1 \times 10^{6}\right.$ cells $\left./ \mathrm{ml}\right)$ spermatozoa preserves their viability, motility and mitochondrial activity for at least $10 \mathrm{~h}$ (Caballero et al., 2006). It is of interest that $\mathrm{Zn}^{2+}$ ions participate in the stabilization of the PSP-I/ PSP-II structure, while low $\mathrm{pH}$ destabilizes this heterodimer (Campanero-Rhodes et al., 2005; RodriguezMartinez et al., 2005). The positive effect on some spermatozoa parameters achieved in our study may be partly caused by the PSPI/PSPII heterodimer present among the zinc-binding proteins.

Our investigations made it possible to state that the analyzed fraction has an advantageous effect on the percentage of cells exhibiting linear movement important for sperm quality. Fluorescence studies showed a stabilizing effect of the zinc-binding proteins on the plasma membranes of spermatozoa incubated at a cold shock temperature $\left(4^{\circ} \mathrm{C}\right)$, and morphological analyses confirmed a positive effect of these proteins on acrosome.

It is possible that the zinc-binding fraction isolated from boar seminal plasma contains some albumin (known as a zinc-binding protein), and a part of the positive results obtained in our experiment could be due to its action. Moreover, albumin has been shown to elimi- 
nate free radicals generated by oxidative stress, enhance sperm motility and protect sperm plasma membrane integrity against cold shock during freezing-thawing of semen (Uysal et al., 2005; Matsuoka et al., 2006).

Our results indicate that proteins binding $\mathrm{Zn}^{2+}$ ions in boar seminal plasma can presumably protect the sperm plasma membrane against cold shock and stabilize spermatozoal acrosome, which may be used in semen preservation for this species. This pertains particularly to the protection of spermatozoa at stages of high semen dilution, which may be used in modern biotechnological methods such as cell sorting and freezing.

\section{Acknowledgements}

Research supported in part by intramural funds of the University of Warmia and Mazury in Olsztyn No. 0103.0803) and KBN grant 2P06D 00128.

\section{REFERENCES}

Al-Somai N, Vishwanath R, Schannon P, Molan PC (1994) Low molecular weight components in bovine semen diffusate and their effects on sperm motility of bull sperm. Reprod Fertil Dev 6: 165-171.

Andrews J, Nolan JP, Hammerstedt RH, Bavister BD (1994) Role of zinc during hamster sperm capacitation. Biol Reprod 51: 1238-1247.

Andrews P (1964) Estimation of molecular weight of proteins by Sephadex gel filtration. Biochemistry 91: 222-227.

Arienti G, Carlini E, De Cosmo AM, Di Profio P, Palmerini CA (1998) Prostasome-like particles in stallion semen. Biol Reprod 59: 309-313.

Bettger WJ, O'Dell BL (1981) A critical physiological role of zinc in the structure and function of biomembranes. Life Sci 28: 1425-1432.

Bjorndahl L (1986) On sperm nuclear zinc and chromatin decondensation. pp 1-32. Karolinska Institute, Stockholm.

Bjorndahl L and Kvist U (2010) Human sperm chromatin stabilization: a proposed model including zinc bridges. Mol Hum Reprod 16: 23-29.

Bjorndahl L, Kvist U, Rodriguez H, Ploen L (1990) Cysteine interacts with a zinc dependent chromatin stability in epididymal boar spermatozoa. Fertilization in mammals. pp 416. eds BD Bavister, J Cummins, ERS Rolan, Serono Symposium, Norwell, MA, USA.

Bjorndahl L, Kjelberg S, Kvist U (1991) Ejaculatory sequence in men with low sperm-chromatin-zinc. Int J Androl 14: 174-178.

Bork P, Beckmann G (1993) The CUB domain. A widespread module in developmentally regulated proteins. I Mol Biol 231: 539-545.

Brandon CI, Heusner G, Caudle AB, Fayrer-Hosken R (1999) Twodimensional polyacrylamide gel electrophoresis of equine seminal plasma proteins and their correlation with fertility. Theriogenology 52: 863-873.

Caballero I, Vazquez JM, Garcia EM, Roca J, Martinez EA, Calvete JJ, Sanz L, Ekwall H, Rodriguez-Martinez H (2006) Immunolocalization and possible functional role of PSP-I/PSP-II heterodimer in highly-extended boar spermatozoa. J Androl 27: 766-773.

Calvete JJ, Raida M, Gentzel M, Urbanke C, Sanz L, Töpfer-Petersen E (1997) Isolation and characterization of heparin and phosphorylcholine-binding proteins of boar and stallion seminal plasma. Primary structure of porcine pB1. FEBS Lett 407: 201-206.

Campanero-Rhodes MA, Menendez M, Sainz L, Calvete JJ, Solis D (2005) Analysis of the stability of the spermadhesin PSP-I PSP-II heterodimer. Effects of $\mathrm{Zn}^{2+}$ and acidic pH. FEBS J 272: 56635670 .

Carlsson L, Ronquist G, Stridsberg M, Johansson L (1997) Motility stimulant effects of prostasome inclusion in swim-up medium on cryopreserved human spermatozoa. Arch Androl 38: 215-221.

Carlsson L, Pahlson C, Bergquist M, Ronquist G, Stridsberg M (2000) Antibacterial activity of human prostasomes. Prostate 44: 279-286.

Centurion F, Vazquez JM, Calvete JJ, Roca J, Sanz L, Perilla I, Garcia EM, Martinez EA (2003) Influence of porcine spermadhesins on the susceptibility of boar spermatozoa to high dilution. Biol Reprod 69: $640-646$

Davis BJ (1964) Disc electrophoresis. Method and application to human serum proteins. Ann NY Acad Sci 121: 404-427.

De Lamirande E (2007) Semenogelin, the main protein of the human semen coagulum, regulates sperm function. Semin Thromb Hemost 33: 60-68.

De Lamirande E, Yoshida K, Yoshiike M, Iwamoto T, Gagnon C (2001) Semenogelin, the main protein of semen coagulum, inhibits human sperm capacitation by interfering with the superoxide anion generated during this process. J Androl 22: 672-679.
De Leeuw FE, Chen HC, Colenbrander B, Verkleij A (1990) Cold-induced ultrastructural changes in bull and boar sperm plasma membranes. Cryobiology 27: 171-183.

Edstrom AML, Malm J, Frohm B, Martellini JA, Giwercman A, Morgelin M, Cole AM, Sorensen OE (2008) The major bactericidal activity of human seminal plasma is zinc-dependent and derived from fragmentation of the semenogelins. I Immunol 181: 3413-3421.

Flowers WL (2001) Relationships between seminal plasma proteins and boar fertility. Ann Swine Rep pp 1-4.

Fraser L, Lecewicz M, Strzeżek J (2002) Fluorometric assessment of viability and mitochondrial status of boar spermatozoa following liquid storage. Polish J Vet Sci 5: 85-92.

Fung KYC, Glode M, Green S, Duncan MW (2004) A comprehensive characterization of the peptide and protein constituents of human seminal fluid. Prostate 61: 171-181.

Gatti JL, Metayer S, Belghazi M, Dacheux F, Dacheux JL (2005) Identification, proteomic profiling, and origin of ram epididymal fluid exosome-like vesicles. Biol Reprod 72: 1452-1465.

Hameed I, Molan P, Shannon P (1991) Nature of large antibacterial proteins in bovine seminal plasma formed by reversible aggregation. NZJ Agric Res 34: 467-470.

Henkel R, Bittner J, Weber R, Huther F, Miska W (1999) Relevance of zinc in human sperm flagella and its relation to motility. Fertil Steril 71: 1138-1143.

Henkel R, Bladauf Ch, Schill WB (2003) Resorption of the element zinc from spermatozoa by the epididymal epithelium. Reprod Dom Anim 38: 97-101.

Hernandez M, Roca J, Calvete JJ, Sanz L, Muinc-Blanco T, CebrianPerez JA, Vazquez JM, Martinez EA (2007) Cryosurvival and in vitro fertilizing capacity postthaw is improved when boar spermatozoa are frozen in the presence of seminal plasma from good freezer boars. I Androl 5: 689-697.

Heukeshoven J, Dernick R (1985) Simplified method for silver staining of proteins in polyacrylamide gels and the mechanism of silver staining. Electrophoresis 6: 103-112.

Hołody D, Strzeżek J (1999) Heparin- and $\mathrm{Zn}^{2+}$-binding proteins from boar seminal plasma. Acta Biochim Pol 46: 935-939.

Jelinkova P, Ryslava H, Liberda J, Jonakova V, Ticha M (2004). Aggregated forms of bull seminal plasma proteins and their heparinbinding activity. Collect Crech Chem Commun 69: 616-630.

Jobim MIM, Oberst ER, Salbego CG, Souza DO, Wald VB, Tramontina F, Mattos RC (2004) Two-dimensional polyacrylamide gel electrophoresis of bovine seminal plasma proteins and their relation with semen freezability. Theriogenology 61: 255-266.

Jonakova V, Ticha M (2004) Boar seminal plasma proteins and their binding properties. A review. Collect Czech Chem Commun 69: 461475.

Jonsson M, Linse S, Frohm B, Lundwall A, Malm J (2005) Semenogelins I and II bind zinc and regulate the activity of prostate-specific antigen. Biochem I 387: 447-453.

Kelly RW, Holland P, Skibinski G, Harrison C, MC Millan L, Hargreave T, James K (1991) Extracellular organelles (prostasomes) are immunosuppressive components of human semen. Clin Experim Immunol 86: 550-556.

Killian GJ, Chapman DA, Rogowski LA (1993) Fertility-associated proteins in Holstein bull seminal plasma. Biol Reprod 49: 1202-1207.

Kravets FG, Lee J, Singh B, Trocchia A, Pentyala SN, Khan SA (2000) Prostasomes: current concepts. Prostate 43: 169-174.

Laemmli UK (1970) Cleavage of structural proteins during the assembly of the head of bacteriophage T4. Nature 227: 680-685.

Lowry IO, Rosenbrough NI, Farr RL, Randall RJ (1951) Protein measurement with Folin phenol reagent. J Biol Chem 193: 263-288.

Malm J, Hellman J, Hogg P, Lilja H (2000) Enzymatic action of prostate-specific antigen (PSA or hK3): substrate specifity and regulation by $\mathrm{Zn}(2+)$, a tight-binding inhibitor. Prostate 45: 132-139.

Matsuoka T, Imai H, Kohno H, Fukui Y (2006) Effects of bovine serum albumin and trehalose in semen diluents for improvement of frozen thawed ram spermatozoa. J Reprod. Dev. 52: 675-683.

Mourvaki E, Cardinali R, Dal Bosco A, Castellini C (2010) In vitro antioxidant activity of the prostatic secretory granules in rabbit semen after exposure to organic peroxides. Biol Reprod Endocrinol 8: 16-23.

O'Farrell PZ, Goodman HM, O'Farrell PH (1977) High resolution of two-dimensional electrophoresis of basic as well as acidic proteins. Cell 12: 113-142.

Piehl LL, Cisale H, Torres N, Capani F, Sterin-Speziale N, Hager A (2006) Biochemical characterization and membrane fluidity of membranous vesicles isolated from boar seminal plasma. Anim Reprod Sci 92: 401-410.

Rehault S, Brillard-Bourdet M, Bourgeois L, Frenette G, Juliano L, Gauthier F, Moreau T (2002) Design of new and sensitive fluorogenic substrates for human kallikrein hK3 (prostate-specific antigen) derived from semenogelin sequences. Biochim Biophys Acta 1596: 55-62.

Robert M, Gagnon C (1999) Semenogelin I: a coagulum forming, multifunctional seminal vesicle protein. Cell Mol Life Sci 55: 944 -960 . 
Rodriguez-Martinez H, Savaria F, Wallgren M, Tienthai P, Johannisson A, Vazquez JM, Martinez E, Roca J, Sanz L, Calvete JJ (2005) Boar spermatozoa in the oviduct. Theriogenology 63: 514-535.

Ronquist G, Brody I (1985) The prostasome: its secretion and function in man. Biochim Biophys Acta 822: 203-218.

Rutherfurd KJ, Swiderek MM, Green CB, Chen S, Shively JE, Kwok SCM (1992) Purification and characterization of PSP-I and PSP-II, two major proteins from porcine seminal plasma. Arch Biochem Biophys 295: 352-359.

Saez F, Motta C, Boucher D, Grizard G (1998) Antioxidant capacity of prostasomes in human semen. Mol Hum Reprod 4: 667-672.

Sanz L, Calvete JJ, Schäfer W, Mann K, Töpfer-Petersen E (1992) Isolation and biochemical characterization of a boar zona pellucidabinding protein. Biochim Biophys Acta 1119: 127-132.

Shannon P, Curson B, Molan PC (1987) Cationic peptides obtained by reversible disaggregation of antibacterial proteins of bovine seminal plasma. NZJ Agric Res 30: 195-202.

Siciliano L, Marciano V, Caprino A (2008) Prostasome-like vesicles stimulate acrosome reaction of pig spermatozoa. Reprod Biol Endocrinol 6: 5-10.

Silverstroni L, Menditto A, Modesti A, Scarpa S (1989) Zinc uptake in human seminal spermatozoa: characterization and effects on cell membranes. Arch Androl 23: 97-103.
Strzeżek J (1999) Seminal plasma and some biological functions of spermatozoa. Adv Cell Biol 26: 59-68.

Strzeżek J, Hopfer E (1987) Zinc ion-dependent protein in boar semen. I. Egg yolk precipitating activity and some biochemical properties. Anim Reprod Sci 13: 117-131.

Strzeżek J, Hopfer E, Zaborniak A (1987) Zinc-ion dependent protein in boar semen. II. Effects on sperm motility and antibacterial properties. Anim Reprod Sci 13: 133-142.

Uysal O, Korkmaz T, Tosun H (2005) Effect of bovine serum albumine on freezing of canine semen. Indian Vet J 82: 97-98.

Vivacqua A, Siciliano L, Sabato M, Palma A, Caprino A (2004) Prostasomes as zinc ligands in human seminal plasma. Int J Androl 27: 27-31.

Watson PF (1975) Use of a Giemsa stain to detect changes in acrosomes of frozen ram spermatozoa. Vet Rec 1: 12-15.

Yoshida K, Kawano N, Yoshiike M, Yoshida M, Iwamoto T, Morisawa M (2008) Physiological roles of semenogelin I and zinc in sperm motility and semen coagulation on ejaculation in humans. MHRBasic Sci Reprod Med 3: 151-156.

Zalensky AO, Yau P, Brenerman JW, Bradbury EM (1993) The abundant 19-kilodalton protein associated with human sperm nuclei that is related to seminal plasma alpha-inhibin. Mol Reprod Dev 36:164 173. 